„Analecta Cracoviensia” 48 (2016), s. 313-329

DOI: http://dx.doi.org/10.15633/acr.2029

Aleksandra Brzemia-Bonarek

Uniwersytet Papieski Jana Pawła II w Krakowie

\title{
Metody odkrycia prawdy procesowej przez sędziego w kanonicznym procesie małżeńskim ${ }^{1}$
}

Reforma procesu małżeńskiego ogłoszona przez papieża Franciszka 15 sierpnia 2015 roku poprzez motu proprio Mitis Iudex Dominus Iesus rozpoczęła dyskusję wśród akademików i praktyków o tożsamości zmian w procesowym prawie małżeńskim (rewolucja czy ewolucja?), ich zasadności, właściwej interpretacji nowych norm, jakości techniki legislacyjnej i zasadności wprowadzenia części pastoralnej ${ }^{2}$. Równocześnie, wraz ze spodziewanym ożywieniem naukowym nad rozlicznymi zagadnieniami związanymi z kościelnym prawem małżeńskim, pojawia się niebezpieczeństwo roztrząsania spraw drugorzędnych, zbytniego skupienia na szczegółach czy też prezentowania karkołomnych i wyszukanych hipotez, które niepoddane rzetelnemu sprawdzeniu w optyce krytyki naukowej staną się jedynie niepotrzebnymi dodatkami.

1 Niniejszy artykuł przedstawia rezultaty badań prowadzonych pod kierownictwem ks. dra hab. Piotra Kroczka w ramach grantu pt. „Klauzule generalne w prawie kościołów i związków wyznaniowych posiadających uregulowany poprzez ustawy stosunek z Rzeczpospolitą Polską" o numerze UMO-2014/13/B/HS5/01482, finansowego przez NCN.

Z pozycji zwartych należy wymienić: G. Boni, La recente riforma del processo di nullità matrimoniale. Problemi, cirticà, dubbi, part 1-3, „Stato, Chiesa e pluralismo confessionale. Rivista telematica" 9-11 (2016), www.statoechiese.it; La riforma dei processi matrimoniali di Papa Francesco. Una guida per tutti, Milano 2016; Proces małżeński według motu priprio Mitis Iudex Dominus Iesus, red. J. Krajczyński, Płock 2015; Praktyczny komentarz do Listu apostolskiego motu proprio Mitis Iudex Dominus Iesus papieża Franciszka, red. P. Skonieczny, Tarnów 2015; L. Sabbarese, R. Santoro, Il processo matrimoniae più breve. Disciplina canonica e riflessi concordatari, Bolonia 2016. 
Codziennym twórczym interpretatorem ustaw jest sędzia. To on zmierza się z tekstem promulgowanym przez ustawodawcę, przekuwając abstrakcyjną normę prawną, często zawierającą w swej treści klauzule generalne, w konkretną rzeczywistość dotykającą drugiego człowieka. Dlatego też zasadna wydaje się konieczność przypomnienia „rzeczy pierwszych”, które są źródłem postawy filozoficznej w spojrzeniu na procesowe prawo małżeńskie i realizacji tych norm w praktyce sądowej.

Jedną z zasadniczych i niezmiennych kwestii (niezależnych od reform prawa) jest służba prawdzie sędziego kościelnego. Niniejszy tekst jest zatem szkicem refleksji nad fascynującym tematem szukania prawdy w sprawach o stwierdzenie nieważności małżeństwa.

\section{Założenie bazowe:}

\section{możliwość odkrycia prawdy o małżeństwie}

Obiektywna, czyli zgodna z rzeczywistością prawda jest celem każdego procesu o stwierdzenie nieważności małżeństwa. Gdy mówimy o prawdzie w sensie klasycznym, mamy na myśli veritas rei. Jednak w sprawach z zakresu wad zgody małżeńskiej, a w szczególności w sprawach, gdzie tytuł nieważności poszukiwany jest w obszarze kanonu $1095 \mathrm{nr} 1-3^{3}$, rozpatrywaną rzeczą (res) powodującą nieważność związku jest wada zgody małżeńskiej, zaś fakty przedstawione sądowi to mało uchwytne zdarzenia dziejące się w sferze umysłu człowieka. Ich subiektywny charakter stanowi w praktyce trudność podczas procesu osiągania przez sędziego moralnej pewności o ważności bądź nieważności badanego małżeństwa. Dlatego też nie sposób, aby kanonista rzetelnie pochylający się nad pracą sądową nie zadawał sobie pytania: na ile i w jakim stopniu jest w stanie odkryć obiektywną prawdę o małżeństwie w sprawach z kanonu 1095 nr 2 i 3, skoro do sądu przychodzą strony każda ze swoją subiektywną prawdą, na poparcie której przedstawiają w większości przypadków równie subiektywnie zeznających świadków? ${ }^{4}$ Pogląd, iż stany emocjonalne

3 Tymi tytułami są: kan. 1095 nr 1 - brak używania rozumu, kan. $1095 \mathrm{nr} 2$ - poważny brak rozeznania oceniającego co do istotnych praw i obowiązków małżeńskich wzajemnie sobie przekazywanych i przyjmowanych, oraz kan. $1095 \mathrm{nr} 3$ - niezdolność do podjęcia istotnych obowiązków małżeńskich z przyczyn natury psychicznej.

4 W sytuacji zaś braku współpracy strony pozwanej z sądem kościelnym (gdyż aktywność procesowa jest obowiązkiem sumienia, a sądy kościelne nie dysponują środkami przymusu, jak to ma miejsce w sądownictwie państwowym) złożenie przez stronę powodową wartościowych dla sprawy dowodów z dokumentu dotyczących współmałżonka graniczy z obiektywną niemożliwością z racji 
człowieka nie dają się wytłumaczyć w sposób logiczny, prezentowali przez długi czas przedstawiciele świata tzw. nauk ścisłych. Sceptycyzm niektórych prawników wobec połączonych osiągnięć nauk przyrodniczych i humanistycznych (np. neuropsychologii) powoduje, iż we współczesnej praktyce sądowej można jeszcze spotkać sędziów, którzy uważając się za prawników „nieskażonych psychologizowaniem”, preferują punkt widzenia uznający, że - inaczej niż w dziedzinie organicznej - w dziedzinie psychicznej (psychiatrii, a szczególnie w psychologii) poznanie intelektualne nie jest z natury swojej oparte na kryteriach obiektywnych. Wydaje się, że główny problem tak przyjętego stanowiska leży w braku wewnętrznego przekonania o możliwości dokonania obiektywnej oceny przedstawionych faktów i dowodów na drodze poznania intelektualnego. W naukach matematyczno-przyrodniczych zastosowanie metod dynamiki nieliniowej i wprowadzenie pojęcia deterministycznego chaosu opisującego sposób pracy mózgu pozwoliło interdyscyplinarnie podejść do problemu i przyjąć, że stany psychiczne człowieka można naukowo opisać i zweryfikowaćs.

Pewność, że prawda jest możliwa do odkrycia, jest podstawą nauki o niej w filozofii chrześcijańskiej. Stanowisko cyników: „prawda, cóż to jest prawda?” (J 18, 38), dyskredytuje możliwość poznania intelektualnego w ogóle. Jest to równocześnie dyskredytowanie człowieka. Jan Paweł II w przemówieniu do Trybunału Roty Rzymskiej w 1980 roku powiedział, iż prawda obiektywna odkrywana przez sędziego w procesie poznania intelektualnego i przy pomocy światła wiary jest „fundamentem, matką i prawem sprawiedliwości”6.

Kościół jest przekonany, o istnieniu obiektywnej prawdy i odkrywalności jej w procesie. W przemówieniach do Roty Rzymskiej od lat 40. Xx wieku do czasów obecnych ${ }^{7}$ papieże przypominają, że prawda o zaskarżonym małżeństwie

restrykcyjnie przestrzeganych ustaw o ochronie danych osobowych oraz autonomii sądownictwa kościelnego i państwowego. O próbach zaradzenia tym lukom dowodowym w ramach wspólnych prac Kościelnej Komisji Konkordatowej i Rządowej Komisji Konkordatowej w latach 2003-2005 odsyła się Czytelnika do artykułu autorki: Pomoc sądowa między sądami państwowymi a sądami kościelnymi. Analiza prawna zagadnienia i propozycje de lege ferenda, [w:] Sędzia i pasterz. Ksiega pamiątkowa z okazji 5o-lecia pracy sądowej ks. Prof. Remigiusza Sobańskiego, red. H. Typańska, Katowice 2007, s. 41-53.

5 W. Klonowski, Chaosensologia. Fizykalistyczna teoria uczuć, [w:] Filozoficzne problemy wiedzy, t. 4: Wiedza a uczucia, red. A. Motycka, Warszawa 2003, s. 214.

6 ...la verità che è fondamento, madre e legge della giustizia. Jan Paweł II, alokucja z 4 lutego 1980 r., AAs 72 (1980), s. 172-178, nr 6.

7 Alokucje do Roty Rzymskiej z 1.10.1942, AAs 34 (1942), s. 338-343. Zob. także następujące alokucje: Z 3.10.1941, AAS 33 (1941), s. 421-426; Z 2.10.1944, AAS 36 (1944), s. 281-290; przemówienie 
jest dla wyrokującego sędziego osiągalna dzięki sprzężeniu rozumu i wiary ${ }^{8}$, zaś zadaniem sędziego w momencie „przedzierania się" przez sferę dowodową jest zdobycie wiedzy o sądzonym małżeństwie, a przez to ukazanie istniejącej i jedynej dla rozpatrywanego małżeństwa prawdy. Sposób poznania jej przez sędziego jest sformalizowany w procedurach dowodzenia i kryteriach oceny dowodów. Omawiając sposób dojścia sędziego kościelnego do obiektywnej prawdy, ks. prof. Remigiusz Sobański zaproponował użycie terminu „prawda prawna", co oznacza prawdę ustaloną przez sędziego zgodnie z jego osobistym poznaniem sprawy (ex sua conscientia) i równocześnie zgodnie z zasadami prawa. Jeżeli sędzia doszedłby do prawdy, pomijając prawo procesowe, to odkryta przez niego prawda mogłaby nie spełnić warunków wymaganych do sprawiedliwego wyroku ${ }^{10}$.

\section{Kryteria dojścia do obiektywnej prawdy}

\section{Pewność moralna}

Pewność moralna jest oryginalną „zdobyczą” prawa procesowego Kościoła; konstrukcją prawną o charakterze generalnym, unikalną - na gruncie innych systemów prawnych ${ }^{11}$. Opisana wprost w kanonie ' $1608 \$ 4$ oznacza taki stopień poznania intelektualnego, który „nie wyklucza absolutnej możliwości czegoś przeciwnego, choć wyklucza uzasadnioną wątpliwość"12. Wprowadzenie do Kodeksu prawa kanonicznego tak rozbudowanego pod względem

Piusa XII do włoskich prawników z 5.12.1954, AAs 48 (1954), s. 60-71. Także alokucje Jana Pawła II Z 4.12.1980, AAS 72 (1980), s. 172-178; z 26.01.1984, AAS 76 (1984), s. 643-649 - dotykają tej materii. Czytelnika zainteresowanego pogłębieniem tematu odsyłam do artykułu Dominique’a le Tourneau, La protection de la vérité dans les discours de le Pape Jean Paul II à la Rote Romaine (1979-2005), „Forum Canonicum” 2 (2007) nr 1, s. 71-86.

8 Przemówienie papieża Benedykta Xvi do Roty Rzymskiej z dnia 27 stycznia 2007 r., „Communicationes” 39 (2007), s. 17-21.

9 R. Sobański, Iudex veritatem de matrimonio dicit, „Ius Matrimoniale” 4 (1999) nr 10, s. 187.

10 Czytelnika zainteresowanego pogłębieniem wiedzy na temat relacji między sprawiedliwością a prawdą odsyła się do artykułu R. Tokarczuka, Sprawiedliwość jako naczelna wartość prawa, „Państwo i Prawo" 1997, nr 6, s. 4-6, gdzie Autor nie tylko zwięźle relacjonuje osiągnięcia filozofii prawa w tej kwestii, lecz nie uchyla się przed postawieniem dalszych pytań i próbuje na nie odpowiedzieć.

1 Z. Grocholewski, Pewność moralna jako klucz do lektury norm procesowych, „Ius Matrimoniale” 3 (1998) nr 9, s. 12.

${ }^{12}$...certezza morale, che cioè escluda ogni dubbio prudente, ossia fondato su ragioni positive. Alokucja Puisa XII z 3.10.1941, AAs 33 (1941), s. 424, nr 3. 
treści filozoficznej pojęcia ma na celu zmobilizowanie w najwyższym stopniu sędziego kościelnego do poszukiwania prawdy, gdyż proces o stwierdzenie nieważności jest - o czym nie można zapominać - procesem o dobro publiczne w Kościele. Za racją istnienia w kościelnym małżeńskim prawie procesowym pewności moralnej nie jako zalecenia czy zadania, lecz nakazu prawnego stoi teologia, z przekonaniem doktrynalnym Kościoła o sakramentalności małżeństwa między ochrzczonymi i o jego nierozerwalności.

Odkrywalna przez sędziego prawda o małżeństwie, jako prawda o sakramencie $^{13}$ (przy współudziale i współodpowiedzialności wszystkich uczestników procesu), była myślą przewodnią kilku przemówień Piusa xıI do Roty Rzymskiej $^{14}$. Zgodnie z historyczną ciągłością małżeńskiego prawa procesowego papież przypomniał, że prawda stanowiąca podstawę każdego wyroku, prawda, do której dochodzi sędzia - to prawda materialna. Istotną cechą pewności moralnej jest obiektywizm, jako kryterium dojścia do prawdy, czyli oparcie się na takich argumentach, zawartych w zdarzeniach znanych wyłącznie $\mathrm{z}$ akt sprawy $^{15}$, które można udowodnić. Wykładnia papieża Piusa XII o pewności moralnej była wielokrotnie przywoływana przez kolejnych papieży, w szczególności zaś „odświeżona” przez Jana Pawła II, który w swoim przemówieniu do Trybunału Roty Rzymskiej z 1980 roku nazwał myśl Piusa XII „autentycznym rozumieniem"16.

Rozważania Piusa XII nad zagadnieniem osiągania przez sędziego kościelnego pewności moralnej są klasyką i kwintesencją nauki prawa procesowego o pewności moralnej jako podstawowym „tworze procesowym” w postępowaniu w sprawach o dobro dusz, a także flagowej cesze kultury prawnej w Kościele.

13 Pius XII, przemówienie $\mathrm{z}$ dnia 2.10.1944, AAS 36 (1944) nr 2.

14 Alokucje z: 3.10.1941, AAS 33 (1941), s. 421-426; 1.10.1942, AAS 34 (1942), s. 338-343; 2.10.1944, AAS 36 (1944), s. 281-290; oraz przemówienie Piusa XII do włoskich prawników Z 5.12.1954, AAS 48 (1954), s. 6o-71.

${ }_{15}$ Kan. $1608 \$ 4$ : ex actis ex probactis.

${ }_{16}$ Pio XII dichiarò in modo autentico il concetto canonico di certezza morale. Jan Paweł II, alokucja z 4.12.1980, nr 6, drugi akapit, AAs 72 (1980), s. 172-178. Wnikliwej analizy zagadnienia pewności moralnej w alokucji Piusa XII dokonał kard. Zenon Grocholewski w artykule Pewność moralna jako klucz do lektury norm procesowych, dz. cyt., s. 9-43. [Ten sam artykuł ukazał w języku włoskim: La certezza morale come chiave delle norme procesuali, „Ius Ecclesiae” 9 (1997), s. 417-450]. O pierwszorzędnej roli prawdy w procesach małżeńskich w nauczaniu Piusa XII pisze R. Sobański: Prawda jako entelechia procesu o nieważność małżeństwa w świetle przemówień Piusa XII do Roty Rzymskiej, „Ius Matrimoniale” 13 (2008) nr 19, s. 29-41. 


\section{Obiektywizm}

Kompletny proces dowodowy jest analizą dedukcyjno-redukcyjną treści informacyjnych (dowodów) umożliwiających ustalenie istotnych dla sprawy faktów. Sędzia w procesie określa ich przydatność i ocenia wiarygodność. Przydatność dowodów analizuje według zasad logiki, doświadczenia życiowego, wiedzy techniczno-przyrodniczej czy tzw. dowodów naukowych. Jak jednak dojść do obiektywnego rozpatrzenia dowodów, które wymykają się prostej systematyzacji i przetwarzaniu logicznemu? Jaką metodę należy przyjąć, analizując takie ulotne i subiektywne dowody jak czyjeś wspomnienia? Inspirując się myślą Bernarda Longerana, kanonista i psycholog kard. Giuseppe Versaldi proponuje szukać wśród przedstawionych w sprawie dowodów wszelkiego rodzaju serii złożonych przyczyn i wydarzeń, które tworzyłyby zespoły przyczynowe (inverse insight) ${ }^{17}$. Poprawność myślenia powinna być weryfikowalna przez schemat powtarzalności takich spraw. Jest to więc rozumowanie powstałe na podstawie wcześniejszych empirycznych badań i obserwacji, przy posiłkowaniu się statystyką jako metodą pozwalającą ów schemat powtarzalności przypadku nazwać.

Nie jest jednak łatwo ustalić sądowi obiektywny stan człowieka ze sformułowań ocennych, które często pojawiają się w zeznaniach świadków ${ }^{18}$. Należy starać się zdefiniować obowiązki małżeńskie, których strona nie była w stanie wypełnić, tak samo jak następnie wykazać korelację między tym obowiązkiem a czynnikiem uniezdalniającym do jego wypełnienia. Małżeństwo jednak nie jest zespołem praw i obowiązków, lecz głęboką wspólnotą życia i miłości ${ }^{19}$, przy czym miłość rozumiemy nie w znaczeniu affectio maritalis znanego z prawa rzymskiego, lecz miłości pełnej, o której w encyklice Humanae vitae pisał papież Paweł vi ${ }^{20}$. Stąd obok pytania o zdolność człowieka do wypełniania konkretnego obowiązku należy zapytać o osobowe zdolności danej

${ }_{17}$ G. Versaldi, Loggettivita delle prove in campo psichico, [w:] Richerche di Scienze Teologiche 19, Brescia 1981, s. 109-119. Versaldi w swojej pracy omawia dzieło B. Longerana, Insight. A study of human understanding wydane w Londynie w 1958 r. (Autorka nie dotarła do egzemplarza cytowanego przez kard. Versaldiego, natomiast zapoznała się cytowaną publikacją i teorią B. Longerana o dwóch - w zależności od natury opisywanej rzeczywistości - sposobach poznania intelektualnego: systematycznego i niesystematycznego, z krytycznego i uzupełnionego wydania: The Collected Works of Bernard Longeran, Toronto 1992).

${ }_{18}$ Np. „była bardzo złą żoną”, „była dziwna”, „była furiatką”, „działał mi na nerwy”, „z takim człowiekiem nie dało się żyć”, „był nieobliczalny”, „nie rozumiał moich potrzeb” itp.

19 Konstytucja Gaudium et spes, n. 48.

${ }^{20}$ Paweł vi, Encyklika Humanae vitae, n. 9. 
osoby do oddania się drugiej osobie i zaakceptowania jej w tak specyficznej relacji międzyosobowej, jaką jest małżeństwo (wyjście poza własne ja, zdolność do postaw altruistycznych, wzajemne oddanie się, troska o współmałżonka itp.). Te pozornie heroiczne cechy, wywołujące u niektórych pesymizm antropologiczny ${ }^{21}$, są w rzeczywistości cechami naturalnie (i obiektywnie) charakteryzującymi na przestrzeni całej historii ludzkości każdy prawdziwy związek małżeński, nie tylko sakramentalny.

Wśród środków prawnych danych sędziemu do obiektywnego wypełnienia swojej funkcji ius dicere znajduje się znana $\mathrm{z}$ teorii prawa konstrukcja uogólnienia przepisów. Abstrakcyjna architektura norm kodeksowych jest dowodem nie tyle zaufania ustawodawcy do prawników, że właściwie zinterpretują przepisy (zgodnie $\mathrm{z}$ „duchem” legislatora), ile wyrazem mądrości i troski o trwałość, wysoką jakość i spójność prawa. W filozofii matematyki uważa się, iż abstrakcja wspomaga poglądowość i przejrzystość rozumowania w konkretnym przypadku ${ }^{22}$. Podobnie jest w prawie: niczym centralne idee przyświecające konkretnemu rozumowaniu, tak struktury abstrakcyjne nie pozwalają sędziemu zagrzebać się w morzu szczegółów, umożliwiają zapoczątkowanie toku kolejnych analiz prowadzących do wysubtelniania pojęć i pobudzają intuicję. Zdarza się bowiem podczas rozważania spraw z zakresu kanonu 1095 nr 2 lub 3, że konkretny problem związany z wątpliwością o ważności bądź nieważności małżeństwa nie daje się wprost rozwiązać (np. biegły nie potrafi wydać pewnej diagnozy lub zaburzenie osobowości według wykonanych testów psychologicznych plasuje się na poziomie subklinicznym). Drobiazgowa analiza kazuistyczna podobnych przypadków tylko zaciemnia rozumowanie. Natomiast odwoływanie się do uogólnionych praw - pozornie trudno uchwytnych - pozwala na rozwiązanie problemu. Ten sposób postępowania sędziego z przestawionymi mu faktami dotyczącymi rozpoznawanego przezeń małżeństwa jest poprawny metodologicznie, a słuszność metody znajduje odzwierciedlenie w podziale uzasadnienia wyroku na część in iure oraz in facto.

Kolejną metodą obiektywizacji subiektywnych dowodów jest uwzględnienie w materiale dowodowym tylko takich elementów, które mają rzeczywiste znaczenie przy rozpatrywaniu ważności lub nieważności małżeństwa z punktu

${ }^{21}$ Benedykt XVI, Alokucja do Roty Rzymskiej z Roty Rzymskiej z 29 stycznia 2009 r., „L'Osservatore Romano” 30.01.2009, s. 7.

${ }_{22}$ M. Grabowski, Emocje i matematyka, [w:] Wiedza a uczucia. Filozoficzne problemy wiedzy, red. A. Motycka, Warszawa 2003, s. 210. 
widzenia prawa kanonicznego. Wzbudza to często niezadowolenie i niezrozumienie stron, iż pozostałe podane przez nich okoliczności - chociaż istotne dla analizy niepowodzenia życia małżeńskiego (np. pojawienie się w sąsiedztwie baru, utrata pracy, emigracja jednego z małżonków, ingerencja teściów itp.) nie są brane przez sąd pod uwagę.

\section{Ekspertyzy biegłych}

Kwestią wartą zasygnalizowania są opinie biegłego, obecnie prawie zawsze występujące $\mathrm{w}$ sprawach $\mathrm{z}$ zakresu wad zgody $^{23}$. Zagadnienie jakości ocen zawartych w tych opiniach wzbudza wiele dyskusji wśród stron i profesjonalnych uczestników procesu. Należy więc zwrócić uwagę na właściwe funkcjonowanie tych ekspertów w procesie. Opinia psychologa, aczkolwiek bardzo przydatna dla sądu, nie wyręcza go z obowiązku krytycznej analizy całości materiału dowodowego $^{24}$. To, co prezentuje test psychologa, jest wyrazem pewnej średniej społeczeństwa. Sędzia feruje wyrok w oparciu o całość materiału dowodowego, nie zaś wyłącznie opierając się o wynik testu i rozmowy biegłego ze stroną (stronami). Nie bez znaczenia jest poziom ryzyka błędu, który sędzia powinien uwzględnić w ramach weryfikacji opinii biegłego. W kwestii rozpatrywania obowiązku określenia przez biegłego występowania lub nie patologii, jej źródeł, ciężkości i wpływu na zdolność konsensualną badanego człowieka do małżeństwa, biegły winien oferować nie mniej, niż mówi norma kanonu 1578 \$2, oraz nie więcej niż opinię psychologiczno-sądową (a nie traktat o moralności lub probabilistyczne propozycje i gdybania), zaś sędzia winien oczekiwać od biegłego zwykłych standardów poprawności metodologicznej i rzetelności naukowej.

Ze szczególną ostrożnością należy używać określeń psychiatrycznych w dyskursie kanonicznym. Biegły ma prawo i obowiązek posiłkować się nazwami chorób i dysfunkcji w swoim oświadczeniu wiedzy. Z kolei w uzasadnieniu wyroku sporządzanym przez sędziego określenia przedstawione przez psychiatrów lub psychologów należy zawsze osadzić w kontekście wyrażeń

${ }^{23} \mathrm{~W}$ tej materii odsyłam do wyczerpującego wykładu psychologii sądowej w odniesieniu do kanonicznego prawa małżeńskiego: G. Zuanazzi, Psichologia e psychiatria nelle cause matrimoniali canoniche, „Studii Giuridici” 73 (2006). Z licznej polskiej literatury na potrzeby niniejszego przedłożenia posiłkowano się w szczególności artykułem Tomasza Rozkruta: Dialog sędziego z biegłym $w$ kanonicznym procesie małżeńskim, „Prawo Kanoniczne” 2011, nr 1-2, w szczególności s. $171-173$.

${ }^{24}$ Papież mówi o „dialogu” sędziego z biegłym. Alokucja z 5.02.1987, AAs 79 (1987), s. 1453-1459. 
kanonistycznych, a szczególności kanonicznej zdolności do małżeństwa. Trzeba pamiętać, że sam fakt występowania choroby psychicznej lub zaburzenia osobowości nie odbiera apriorycznie ius connubii. Choroba nie jest tytułem nieważności, lecz przesłanką do zakotwiczenia nieważności małżeństwa w tytule prawnym znajdującym się w kodeksie. Obiektywizm i niezależność sędziego jako jedne $\mathrm{z}$ funkcji gwarancyjnych w procesie odkrywania prawdy każą spojrzeć na biegłego z życzliwością (wszak jest często ważną pomocą w procesie wyrokowania ${ }^{25}$ ), ale i z krytycyzmem. To nie psychiatra czy psycholog decyduje o prawnej ważności małżeństwa, lecz sędzia jako podmiot władzy sądowniczej w Kościele ${ }^{26}$. Dialog sędziego z biegłym ma być dyskusją dwóch intelektualistów patrzących na tę samą rzeczywistość społeczną (zaskarżone małżeństwo) z perspektywy różnych nauk: humanistycznej i teologiczno-społecznej, ale równocześnie nauk opartych na tych samych wartościach filozoficznych, to jest: humanizmie teocentrycznym i antropologii chrześcijańskiej.

\section{Co zaburza obiektywizm sędziego?}

W przypadkach wad zgody najbardziej zaciemnia rzeczywisty obraz spraw silna subiektywizacja przytoczonych faktów przez strony lub świadków. Dlatego też ogromnie ważne jest właściwe przygotowanie pytań dla zeznającego oraz stworzenie takiej atmosfery podczas przesłuchania, która pozwoli stronie czy świadkowi odpowiadać spokojnie, spontanicznie, a równocześnie jak najbardziej ściśle, z podaniem maksymalnej liczby faktów - a nie osobistych ocen. Oczywiście, oprócz staranności w przygotowaniu pytań, sam audytor musi charakteryzować się elastycznością przy prowadzeniu przesłuchania, w ramach granic określonych zakresem i przedmiotem zagadnieńn ${ }^{27}$. Dalsze występujące zaburzenia w procesie obiektywizacji dowodów to błędy logiczne sędziego: dopatrywanie się wzorów tam, gdzie ich nie ma, niewłaściwa interpretacja niekompletnych danych, wybiórcze zwracanie uwagi na te tylko

${ }_{25}$ Zostało to podkreślone w nowych normach procesu małżeńskiego - kanonie $1678 \$ 1$ zmieniającym dotychczasowe brzmienie kanonu 1680 kodeksu z 1983 r. (papież Franciszek, Motu proprio Mitis Iudex Dominus Iesus), odnoszących się do obecności biegłych. Zob. komentarz Tomasza Rozkruta na s. 111-114 w: Praktyczny komentarz do Listu apostolskiego „Mitis Iudex Dominus Iesus Motu proprio” papieża Franciszka, red. P. Skonieczny op, Tarnów 2015.

26 R. L. Burke, Canon 1095. Canonical doctrine and jurisprudence, part 1: Canon $1095 \$ 1$ and 2, [w:] Proceedings of the 45th Annual Convenction of CLSA, Washington 1984, s. 94-107.

${ }_{27}$ Szeroko zagadnienie to potraktował Gianfrancesco Zuanazzi, Psichologia e psychiatria..., dz. cyt., s. $285-297$. 
informacje znajdujące się w aktach sprawy, które potwierdzają z góry podjęte przez sędziego tezy o ważności lub nieważności małżeństwa.

Zdarzająca się w opiniach biegłych samowolność w wystawianiu oceny dotyczącej wprost istnienia bądź nieistnienia małżeństwa może w niektórych przypadkach poważnie skrępować u sędziego wysiłek poszukiwania prawdy, czyli zaburzyć krytycyzm i obiektywizm poznania sędziowskiego. Takie przypadki, choć rzadkie, mają miejsce szczególnie wtedy, gdy w sądzie ów biegły cieszy się autorytetem pracowników trybunału i ma naturalne skłonności wypowiadania swojego zdania w każdym przypadku. Sędzia powinien pamiętać, jakie jest zadanie biegłego (ustalenie przyczyn zaburzeń, stopnia i natury tychże oraz skutków). Nie może oczekiwać, że biegły odpowie mu na pytanie o ważność lub nieważność małżeństwa. Nie może również czuć się takim sądem związany ${ }^{28}$.

Nie sposób nie wspomnieć o rutynie jako o mieczu obosiecznym w procesie odkrywania prawdy o małżeństwie. Z jednej strony jest to bowiem cenna cecha, dzięki której sędzia szybciej i z większą pewnością zauważa charakterystyczne dla rozpatrywanego przypadku typowości. Z drugiej zaś strony rutyna może przesłonić sędziemu staranność wyrokowania. Sprawy mogą być nieraz analogiczne - nigdy jednak nie są identyczne. Stale wyrokując według wcześniej powziętych schematów, sędzia staje się subiektywny i sztywny w swej ocenie. Rutyną należy się umiejętnie posługiwać. Są obszary, w których jest ona pożądana, i takie, w których mocno szkodzi. Można np. rutynowo przygotować pytania - i będą one poprawne, chociaż bardzo dobre będą te pytania, które uwzględnią indywidualizm sprawy i odniosą się wprost do wcześniejszej aktywności sądowej stron ${ }^{29}$. Natomiast rutynowa interpretacja zeznań może spowodować powierzchowne, a nawet błędne zrozumienie przedstawionych faktów.

Wreszcie, orzeczenie nieważności nie może być narzędziem zaspokojeń subiektywnych pragnień, nawet jeśli pobudki stron wynikają z ich wrażliwości religijnej. Strony (a nierzadko proboszczowie stron) piszą na przykład w pismach procesowych następujące zdania: „proszę, aby Sąd przychylił się i zastosował nadzwyczajne środki, które warunkowo pozwalają na wydanie wyroku pozytywnego"30. Działanie sędziego poddające się temu myśleniu nie doprowadzi

${ }^{28}$ Jan Paweł II, Alokucja z 5.02.1987, AAs 79 (1987) nr 8.

${ }_{29}$ Skargi powodowej, odpowiedzi na skargę, pisma wyjaśniającego, protokołu z przesłuchania, noty sądowej, dołączonych do pism procesowych dowodów itp.

30 Fragment autentycznego pisma procesowe powoda. Archiwum Sądu Metropolitalnego w Krakowie, sygn. IN 66/o4. (Cytowane za zgodą Oficjała tegoż sądu). 
do blasku prawdy, lecz będzie fałszywym działaniem pastoralnym, przed którym przestrzegał Jan Paweł II, a co przypomniał w 2007 roku Benedykt XVI ${ }^{31}$.

\section{Swobodna ocena dowodów}

W odkryciu obiektywnej prawdy pomaga sędziemu swobodna ocena dowodów, czyli analiza materiału dowodowego według jego wartości dla procesu na podstawie osobistego przeświadczenia sędziego, przy pomocy zasad logicznego myślenia i własnego doświadczenia ${ }^{32}$. Zasada ta nie oznacza jednak samowolności i ściśle wiąże się z koncepcją prawdy materialnej, a nie formalnej ${ }^{33}$. W wiekach średnich scholastyczne środowisko naukowe generalnie hołdowało formalnej teorii wyrokowania, chociaż papieże Klemens III, Celestyn III czy Innocenty IV podkreślali konieczność dojścia sędziego do prawdy materialnej (obiektywnej) $)^{34}$. Już w momencie formowania się kanonistyki jako niezależnej dyscypliny naukowej bezsporne było, że w przypadku tzw. causes spirituales (do których należały procesy małżeńskie) prawda odkrywana przez sędziego ma oznaczać zgodność orzeczenia $z$ istnieniem bądź nieistnieniem węzła małżeńskiego - sakramentu, przy poszanowaniu zasad sprawiedliwości i słuszności. Innymi słowy ma to być prawda obiektywna. Z tej właśnie koncepcji prawdy wyrasta zasada, iż sprawy dotyczące stanu osób nie przechodzą w stan rzeczy osądzonej, czego konsekwencją jest istniejący od XIII wieku zakaz przywrócenia do stanu pierwotnego (restitutio in integrum) w sprawach małżeńskich ${ }^{35}$. Podobnie jak Kodeks prawa kanonicznego z 1917 roku, tak i obecnie obowiązujący nakłada na sędziego

${ }^{31}$ Jan Paweł II, Przemówienie z 18.01.1990, AAs 82 (1990), s. 872-877, nr 3; Jan Paweł II, Alokucja z 28.01.1994, AAs 86 (1994), s. 947-952, nr 5; Benedykt XVI, Alokucja z 27 stycznia 2007 r., „Communicationes” 39 (2007), s. 17-21. Zagadnienie to - jako jedno z kilku analizowanych z problemów badawczych - podejmuje bardziej szczegółowo Andrzej Pastwa w artykule: Favor matrimonii i certitudo moralis (kan. $1608 \$ 4$ ) - strukturalne filary teleologii procesu o nieważność małżeństwa, „Prawo Kanoniczne” 2011, nr 1-2, s. 232.

${ }^{32}$ Szczegółowo zagadnienie pewności moralnej i swobodnej oceny dowodów potraktował Joaqiun Llobell, Oggettività e soggettività nelle valutazione giudiziaria delle prove, „Quaderni di diritto ecclesiale" 14 (2001), s. 394-413.

$33 \mathrm{~W}$ formalnej ocenie dowodów sędzia związany był ustalonymi przez ustawodawcę zasadami dotyczącymi interpretacji dowodów i konsekwencji prawnych z nich wynikających.

34 X.I.9.C.6., X.II.2O.c.27, C.1.II.14.in VI. Ówczesnym prawnikom znane było stanowisko cesarza Hadriana (pierwsza połowa II w.) który zachęcał, aby sędziowie, wyrokując, poszukiwali prawdy obiektywnej, wspomagając się swobodą własnego sumienia. Digesta 22, 5. 3. 2.

35 Sententia lata contra matrimonium numquam transit in rem iudiatam. c.11, x, De sententia et re iudicata, II, 27. Glosa Permanere. 
kościelnego obowiązek dojścia do prawdy obiektywnej i zapewnia mu środki prawne niezbędne do realizacji wspomnianego celu. Ogłoszona w 2005 roku instrukcja procesowa Dignitas connubii w artykule 247 uwypukla w swoich normach obowiązek zasądzenia zgodnego z rzeczywistym stanem rzeczy. Nie inaczej ma to miejsce w znowelizowanych przez papieża Franciszka przepisach kanonicznego prawa procesowego ${ }^{36}$. Nakaz osiągnięcia prawdy obiektywnej nie może zostać osłabiony żadnymi racjami pastoralnymi ${ }^{37}$, gdyż blask prawdziwej sprawiedliwości jest blaskiem prawdy, która realizuje się w nadrzędnej kodeksowej zasadzie dobra dusz (salus animarum) $)^{38}$.

Sędzia musi starannie zbadać wszystkie przedłożone mu dowody, dbając, aby żadne istotne elementy nie umknęły jego uwadze. Także inne powstałe przed sądem sytuacje, takie jak subiektywne interpretacje faktów przez strony, luki pamięci odnośnie do pewnych wydarzeń dowodzonych przed sądem, czyjeś braki należytej staranności, a nawet akty złej woli wchodzą pod osąd sędziego odnośnie do rozstrzyganej sprawy.

Znajdujące się w kodeksie normy wiążące sędziego z faktami i dowodami ograniczają możliwość jego arbitralności. Jednocześnie w procesie o dobro publiczne Kościoła (a takim jest proces o stwierdzenie nieważności małżeństwa) dyskrecjonalność sędziego jest ogromna ${ }^{39}$. Aby swobodna ocena dowodów nie stała się samowolna, w kodeksie funkcjonują wynikające $\mathrm{z}$ wielowiekowej tradycji i doświadczenia jurystów, a poparte zasadami logicznego myślenia dyrektywy o znaczeniu ogólnym (nakazy bądź zakazy dowodowe $)^{40}$. Przyczyniają się one do właściwego spojrzenia na środki

${ }^{36}$ Piotr Skonieczny oP w syntetyczny sposób przedstawił ciągłość i aktualność myśli kanonicznej o pewności moralnej w komentarzu art. 12 Ratio (wskazówki interpretacyjnej) wprowadzonego poprzez motu proprio Mitis Iudex Dominus Iesus papieża Franciszka. Zob. Praktyczny komentarz..., dz. cyt., s. 156-159.

37 Należy jednoznacznie podkreślić, że wprowadzony przez papieża Franciszka proces skrócony przed biskupem nie zwolnił sędziego (tu: biskupa) z obowiązku osiągnięcia pewności moralnej dla deklaracji wyroku pozytywnego, to jest pro nulitatae. Szybkość procesu nie może w żaden sposób spowodować sprzeniewierzenia się prawdzie i sprawiedliwości. Ramy niniejszego artykułu nie pozwalają na bliższe zajęcie się tym interesującym tematem. Czytelnika odsyła się do krótkiego, acz wnikliwego krytycznego spojrzenia na nowy kanon $1687 \$ 1$ CIC/MIDI autorstwa Piotra Majera w publikacji: Praktyczny komentarz..., dz. cyt., s. 184-192.

${ }^{8}$ Kanon 1752.

39 Kanon 1505, 1598 to jest: możliwość nieprzyjęcia skargi procesowej czy kwestia decyzji o utajnieniu części akt.

40 Np. nakazy dowodowe, kanony: 1526, 1536, 1585, 1541, 1573. Zakazy dowodowe: kanony 1546 $\S 1$ oraz $1548 \$ 2,1550 \$ 1$ i 2 . 
dowodowe, w których występują pewne typowości. Wspomagają również sędziego w jego obiektywizmie. Innymi słowy, zakazy i nakazy dowodowe pomagają ustalić wspomnianą wcześniej prawdę prawną. Jednak reguły dowodzenia nie są celem samym w sobie - służą one osiągnięciu obiektywnej prawdy ${ }^{41}$. Automatyczne ich przestrzeganie nie gwarantuje zgodnego z prawdą wyroku, gdyż sędzia nie jest robotem zaprogramowanym do wydawania orzeczeń, lecz człowiekiem ograniczonym w charakterystycznym i unikalnym dla niego postrzeganiu świata.

\section{Charakterystyka sędziego dążącego do prawdy}

W każdym wyroku sędzia daje coś z siebie, nie tylko w formie i stylu, ale i w rozpoznaniu ${ }^{42}$. Stąd nie sposób przecenić formacji zarówno naukowej, jak i osobowej sędziów ${ }^{43}$. Papież Jan Paweł II przypomniał, iż sędzia powinien odrzucić strach przed wyrokowaniem zgodnym z prawdą, nawet jeżeli oznaczałoby to niezadowolenie czy gniew stron (lub strony) ${ }^{44}$. Musi być gotowy do przyjęcia prawdy i mieć odwagę ją przepowiadać.

W swoim ostatnim przemówieniu do Roty Rzymskiej 29 stycznia 2005 roku Ojciec Święty powiedział, iż to „miłość do prawdy jest podstawowym kryterium określającym sędziego" 45 .

Specyficzność i trudność spraw z zakresu poważnego braku rozeznania oceniającego lub niezdolności do podjęcia i wypełnienia istotnych obowiązków małżeńskich związana jest z tym, iż mamy do czynienia z okolicznościami, które dzieją się w sferze psychicznej człowieka. Same fakty mają więc

${ }_{41}$ P. A. Bonnet, Le prove nel giudizio ecclesiale, „Periodica” 98 (2009), s. 235-273: Il processo si costruisce sia constituido dalla verita, cosicche puo dirsi che a'attivita processuale non solo nasce e muore, ma certamente vive tutta la sua vita nel segno del diritto divino, e cioe della verita che, sempre ed in ogni caso coincident con la salvezza delle anime, costituisce per la Chiesa la sua legge suprema.

42 R. Sobański, Uwagi o tożsamości sędziego kościelnego, „Prawo Kanoniczne” 45 (2002) nr 3-4, s. 11; J. A. Coriden, Rules for interpreters, „The Jurist” 42 (1982), s. 277-303. (All law is applied by persons. No law works automatically, nor is its application a purely mechanical robot).

43 Kardynał Zenon Grocholewski zwraca uwagę, iż cechy osobowościowe sędziego są pierwszym czynnikiem prawidłowego orzekania. Pewność moralna..., dz. cyt., s. 33.

${ }_{44}$ La deontologia del giudice ha il suo criterio inspiratore nellamore per la verità. Egli dunque deve essere innanziutto convinto che la verità esiste. [...] Bisogna resistere alla paura della verità, che a volte può nascere dal timore di urtare le persone. Alokucja Jana Pawła II z 29.01.2005, AAS 93 (2005), s. 165, nr 5.

45 Alokucja Jana Pawła II Z 29.01.2005, AAs 93 (2005), s. 165, nr 5. 
psychiczny, trudny do uchwycenia charakter. Zaistnienie małżeństwa lub też nie ustalamy poprzez analizę stanu psychicznego człowieka, czyli takiej aktywności mózgu, która jest ocenna i dynamiczna. Wspomniane stany psychiczne równocześnie omawiamy w relacji do zdolności człowieka do życia w małżeństwie ${ }^{46}$. Dynamiczny i podmiotowy aspekt norm dotyczących wad woli wymaga holistycznego spojrzenia na człowieka i jego małżeńską relację.

Sędzia, który odkrywa prawdę w procesie, jest jak badacz w nauce. Obowiązek uzasadnienia wyroku przez trybunał oznacza, iż sędzia musi się właśnie „naukowo” zmierzyć z własnym osądem. Ksiądz prof. Remigiusz Sobański nie tylko wybitny uczony, ale i wieloletni sędzia kościelny - napisał w jednym $\mathrm{z}$ artykułów poświęconych funkcji sędziego: „od tego, jak sąd uzasadnia swe orzeczenia, zależy jego prestiż" ${ }^{77}$. W ramach gotowości do przyjęcia prawdy sędzia winien wykazywać się umiejętnością słuchania, respektowania i przyjmowania do wiadomości tego, co pojawia się w toku procesu. Jako osoba ogłaszająca wyrok sędzia ma mieć stałą chęć do poszerzania horyzontu własnego rozumienia. Ten, którego świat już nie zadziwia i nie fascynuje, który „wszystko już widział i wszystko wie”, może nie odkryć prawdy o małżeństwie w sytuacji atypowej. Prawo należy do grupy nauk społecznych, lecz sprawy małżeńskie z kanonu 1095 nr 3 w ogromnym stopniu dotykają sytuacji, w których bardzo szybki jest postęp w dziedzinie nauk medycznych i psychologicznych. Nie można żądać od sędziego znajomości najnowszych badań i wytycznych naukowych z innych niż prawo dziedzin - wszak sędzia nie musi być omnibusem. Jednak należy wspomnieć o pożytecznej dla jakości wyrokowania gotowości sędziego do uznawania akceptowalnych w środowisku naukowym najnowszych wyników nauk przyrodniczych. Właściwie wprzęgnięta w postępowaniu dowodowym nauka pomaga $\mathrm{w}$ procesie małżeńskim $\mathrm{z}$ prawdziwych przesłanek wyciągnąć prawdziwe wnioski. Warunkiem opisanej powyżej otwartości jest popperowski krytycyzm wobec siebie i wobec innych ${ }^{48}$.

${ }^{46}$ Może się przecież okazać, że osoba z powodzeniem wypełniająca swoje funkcje społeczne i zawodowe nie potrafi stworzyć prawdziwego małżeństwa.

47 R. Sobański, Uwagi o funkcji sędziego w procesie o nieważność małżeństwa, „Ius Matrimoniale” 3 (1998) nr 9, s. 51.

${ }^{48}$ Myśl naukowa Karla Poppera i krytycyzm jako kryterium poprawności metody naukowej: „za poprawne uznajemy te tezy, które jesteśmy w stanie dowieść. Prawdziwość ich istnie dopóki, dopóty nie udowodni się czegoś przeciwnego" - dały podwaliny współczesnej filozofii nauki. 


\section{Wnioski. Jaka prawda i jak osiągnięta?}

Obiektywna prawda o małżeństwie to deklaracja sędziego o zaistnieniu bądź niezaistnieniu przymierza od momentu składania aktu woli przez nupturienta. Jest to więc prawda początku, jak powiedział w 2007 roku papież Benedykt XVI ${ }^{49}$. Również o braku prawdy początku w nieważnym małżeństwie mówili prawnicy średniowieczni, gdy w procesie formułowali deklarację: non fuit matrimonium ab initio in veritate ${ }^{50}$. Na podstawie wcześniejszych rozważań można przyjąć, iż definicja prawdy odkrytej w procesie o stwierdzenie nieważności małżeństwa nie jest prawdą o instytucji, lecz prawdą o człowieku w jego relacji małżeńskiej do drugiego człowieka. Będąc prawdą „obiektywną”, oznacza ona, iż wydany osąd jest zgodny z rzeczywistością. Prawda ta zostaje osiągnięta przez sędziego z pewnością moralną, w procesie poznania intelektualnego, przy zastosowaniu poprawnej metody kanoniczo-prawnej, ograniczona normami procesowymi (stąd jest to równocześnie prawda prawna), lecz nie zniewolona nimi, gdyż sędzia posługuje się swobodną oceną dowodów (czyli rozważa je w swoim sumieniu i przy użyciu zasad doświadczenia życiowego). Prawda ta powstaje również jako wynik wspólnotowego zaangażowania i zobowiązania wszystkich uczestników procesu do jej poszukiwania: obrońcy węzła, adwokata, stron, świadków, notariusza, biegłego, kuratora czy - jeśli występuje - rzecznika sprawiedliwości. Jest to też prawda, w której sędzia dał coś z siebie i był świadom tego indywidualnego śladu. Tak orzeczona prawda określa zdolność do małżeństwa konkretnego człowieka i warunkuje sposób jego dalszego życia w Kościele. Równocześnie jest to prawda o prawnym pochodzeniu małżeństwa jako części Bożego planu wobec ludzkości ${ }^{51}$.

49 Przemówienie papieża Benedykta xvi do Roty Rzymskiej z dnia 27 stycznia 2007 r., „Communicationes” 39 (2007), s. 17-21.

5o Gracjan C.32, q.7, c.2 ... declaratur matrimonium non fiusse. Interesująco omówienia tematu dokonał Jean Gaudemet w monografii: Storia del diritto canonico. Ecclesia et civitas, Milano 1998, s. 562 .

${ }^{51}$ Benedykt XVI do Roty Rzymskiej z dnia 27 stycznia 2007 r., „Communicationes” 39 (2007), S. $17-21$. 


\section{ABstrakt}

\section{Metody odkrycia prawdy procesowej przez sędziego}

\section{w kanonicznym procesie małżeńskim}

Niniejszy artykuł w swoich założeniach: „najpierw rzeczy pierwsze”, ma na celu zwięzłe przypomnienie o nadrzędnej wartości kanonicznego procesu małżeńskiego jaką jest prawda obiektywna, do której, poprzez różne metody poznania intelektualnego musi dojść sędzia kościelny badający sprawę o stwierdzenie nieważności małżeństwa. Autorka wskazuje i krótko opisuje kryteria pozwalające sędziemu poznanie prawdy w procesie takie jak: pewność moralna, swobodna ocena dowodów, obiektywizm. Zwraca również uwagę na charakterystykę osoby sędziego jako badacza sprawiedliwości. W publikacji przywołane zostają cechy i postawy, które wspomagają sędziego w przepowiadaniu prawdy, ale które mogą w pewnych okolicznościach osłabić też jego obiektywizm. Tenor myśli przewijającej się w pracy jest następujący: żadne racje pastoralne nie osłabiają nakazu osiągnięcia przez sędziego prawdy obiektywnej. Ta bowiem zawiera się w fundamentalnej kodeksowej zasadzie salus animarum.

\section{SŁOWA KLUCZOWE}

kanoniczny proces małżeński, prawda obiektywna, pewność moralna, sędzia kościelny

\section{Abstract}

The methods of unveiling the truth in the matrimonial nullity process by a judge The assumptions of the above article, according to "first things first" rule, is to briefly remind the superior value of the matrimonial nullity process which is the objective truth. While investigating the case the ecclesiastical judge has to achieve such truth through a variety of methods of the intellectual knowledge. The author indicates and compactly describes the criteria for the judge to accomplish the truth in the process such as moral certitude, free assessment of evidence and objectivity. In the article, the attention is focused on the personality of a judge as the researcher of justice. The publication cites some characteristics and attitudes that assist the judge in the preaching of the truth but can also - under some circumstances - weaken its objectivity. The main idea of this work stipulates that no pastoral reasons could impair the moral and legal requirement to achieve the material truth in the canonical matrimonial process. This fact is contained in the Code of Canon Law as the fundamental principle of salus animarum.

\section{KEYWORDS}

matrimonial nullity proces, objective truth, moral certitude, ecclesiastical judge 


\section{BIBLIOGRAFIA}

Bonnet P. A., Le prove nel giudizio ecclesiale, „Periodica” 98 (2009), s. 235-273.

Brzemia-Bonarek A., Pomoc sądowa między sądami państwowymi a sądami kościelnymi. Analiza prawna zagadnienia i propozycje de lege ferenda, [w:] Sędzia i pasterz. Księga pamiątkowa z okazji 5o-lecia pracy sądowej ks. Prof. Remigiusza Sobańskiego, red. H. Typańska, Katowice 2007, s. 41-53.

Burke R. L., Canon 1095. Canonical doctrine and jurisprudence, part 1: Canon 1095 $\$ 1$ and 2, [w: Proceedings of the 45th Annual Convenction of CLSA, Washington 1984, s. 94-107.

Corriden J. A., Rules for interpreters, „The Jurist” 42 (1982), s. 277-303.

Gaudamet J., Storia del diritto canonico. Ecclesia et civitas, Milano 1998.

Grabowski M., Emocje i matematyka, [w:] Wiedza a uczucia. Filozoficzne problemy wiedzy, red. A. Motycka, Warszawa 2003.

Grocholewski Z., Pewność moralna jako klucz do lektury norm procesowych, „Ius Matrimoniale" 3 (1998) nr 9, s. 9-43.

Klonowski W., Chaosensologia. Fizykalistyczna teoria uczuć, [w:] Filozoficzne problemy wiedzy, t. 4: Wiedza a uczucia, red. A. Motycka, Warszawa 2003.

Llobell J., Oggettività e soggettività nelle valutazione giudiziaria delle prove, „Quaderni di diritto ecclesiale" 14 (2001), s. 394-413.

Longeran B., Insight. A study of human understanding, [w:] The collected works of Bernard Longeran, Toronto 1992.

Majer P., Kanon 1687\$1 CIC/MIDI, [w:] Praktyczny komentarz do Listu apostolskiego „Mitis Iudex Dominus Iesus Motu proprio” papieża Franciszka, red. P. Skonieczny OP, Tarnów 2015, s. 184-192.

Pastwa A., Favor matrimonii i certitudo moralis (kan. $1608 \$ 4$ ) - strukturalne filary teleologii procesu o nieważność małżeństwa, „Prawo Kanoniczne” 2011, nr 1-2, s. 217-245.

Rozkrut T., Dialog sędziego z biegłym w kanonicznym procesie małżeńskim, „Prawo Kanoniczne" 2011, nr 1-2, s. 161-174.

Rozkrut T., Kanon 1678 \$ 3 CIC/MIDI, [w:] Praktyczny komentarz do Listu apostolskiego „Mitis Iudex Dominus Iesus Motu proprio” papieża Franciszka, red. P. Skonieczny OP, Tarnów 2015, s. 111-114.

Skonieczny P., Ratio art. 12, [w:] Praktyczny komentarz do Listu apostolskiego „Mitis Iudex Dominus Iesus Motu proprio" papieża Franciszka, red. P. Skonieczny op, Tarnów 2015, s. 156-159.

Sobański R., Uwagi o funkcji sędziego w procesie o nieważność małżeństwa, „Ius Matrimoniale" 3 (1998) nr 9, s. 45-61. 